\title{
Olmesartan: A Little-Known Cause of Diarrhoea
}

\author{
Joana Serôdio $^{1}$, Joana Carneiro ${ }^{1}$, Manuel Veiga ${ }^{2}$, António Ferreira ${ }^{1}$ \\ ${ }^{1}$ Internal Medicine Department, Unidade Local de Saúde do Alto Minho, Portugal \\ ${ }^{2}$ Anatomical Pathology Department, Unidade Local de Saúde do Alto Minho, Portugal
}

Received: 05/05/2019

Accepted: $16 / 05 / 2019$

Published: $28 / 06 / 2019$

How to cite this article: Serôdio J, Carneiro J, Veiga M, Ferreira A. Olmesartan: a little-known cause of diarrhoea. EJCRIM 2019;6:

doi:10.12890/2019_001143.

Conflicts of Interests: The Authors declare that there are no competing interest

This article is licensed under a Commons Attribution Non-Commercial 4.0 License

\section{ABSTRACT}

Olmesartan's sprue-like enteropathy was first described in 2012 and typically presents with diarrhoea, weight loss, nausea, vomiting, low albumin and histological evidence of intestinal villous atrophy. Coeliac disease is one of the main differential diagnoses and should be excluded. We present the clinical case of a 63-year-old man treated with olmesartan for 10 years who presented with a 2-month history of diarrhoea and was diagnosed with olmesartan's enteropathy. This case highlights the need for clinical suspicion of this new entity in order to reduce the associated morbidity and unnecessary costly investigations.

\section{LEARNING POINTS}

- Sprue-like enteropathy associated with olmesartan is a recently described and recognized disease.

- This condition should be suspected in patients taking olmesartan who have chronic diarrhoea, intestinal villous atrophy and negative serology for coeliac disease, or an absent response to a gluten-free diet.

- Early suspicion of olmesartan's enteropathy can reduce the associated morbidity and avoid costly investigation.

\section{KEYWORDS}

Olmesartan, diarrhoea, villous atrophy

\section{INTRODUCTION}

Olmesartan is one of several angiotensin II receptor antagonists available for the treatment of arterial hypertension. Sprue-like enteropathy caused by this drug was first described in $2012^{[1]}$ with a few cases subsequently reported. Patients typically present with diarrhoea, weight loss, nausea, vomiting and low albumin. Coeliac disease is one of the main differential diagnoses and although biopsy findings may be similar in both entities, olmesartan-induced enteropathy occurs in the presence of normal coeliac serologies and, importantly, in the absence of a response to a gluten-free $\operatorname{diet}^{[1]}$. We present the case of a patient with a 2-month history of diarrhoea who had been under treatment with olmesartan for 10 years.

\section{CASE DESCRIPTION}

A 63-year-old male patient was admitted through the emergency department with a 2-month history of watery diarrhoea of 6-10 stools a day, abdominal pain that woke him up at night, anorexia and weight loss of $10 \mathrm{~kg}$. No fever or other symptoms were reported. He had been previously medicated with ciprofloxacin and sulfamethoxazole/trimethoprim for possible small bowel bacterial overgrowth without improvement. The patient had also undergone a colonoscopy and upper gastrointestinal endoscopy which were both normal.

The patient had history of arterial hypertension and dyslipidaemia and had been medicated with olmesartan/hydrochlorothiazide $20 / 12.5$ mg once daily for 10 years, atenolol 100 mg once daily, lercanidipine 20 mg once daily, clonidine 0.15 mg three times daily, and simvastatin 
$20 \mathrm{mg}$ once daily. He lived in the countryside and drank well water that was not submitted to microbiological tests. He had no history of allergies, alcohol intake, contact with animals or recent travels abroad.

At admission the patient was conscious with normal vital signs. His weight was $99 \mathrm{~kg}$ with a body mass index of $29.89 \mathrm{~kg} / \mathrm{m}^{2} . \mathrm{Abdominal}$ examination was unremarkable and no peripheral oedema or adenopathies were present.

Blood tests revealed a haemoglobin of $14.4 \mathrm{~g} / \mathrm{l}$, white blood cells of $10.04 \times 10^{9} / \mathrm{l}$, C-reactive protein of $0.16 \mathrm{mg} / \mathrm{dl}$, erythrocyte sedimentation rate of $18 \mathrm{~mm}$, albumin of $4.4 \mathrm{~g} / \mathrm{dl}$, sodium of $137 \mathrm{mmol} / \mathrm{l}$, potassium of $3.7 \mathrm{mmol} / \mathrm{l}$, low folic acid (2.5 mg/dl) and normal liver enzymes (Table 1). Abdominal ultrasound was normal. The patient was discharged to the outpatient clinic and was treated with metronidazole on the assumption he had a protozoal infection, without improvement. He lost another $5 \mathrm{~kg}$, developed hypoalbuminaemia of $2.9 \mathrm{mg} / \mathrm{dl}$ and hypokalaemia with a need for oral supplementation. An extended study was then performed.

Laboratory evaluation revealed thyroid function, cortisol level, protein electrophoresis, antinuclear antibodies and coeliac auto-antibodies were all normal. HIV and viral hepatitis tests were negative. Fasciola, Entamoeba and Giardia serological tests were negative, and gastrin and VIP levels were normal (Table 1).

Bacteriological, mycobacteriological, parasitological and clostridium stool tests were negative. Stool osmolarity was normal, and tests for reducing sugars and fat were negative.

\begin{tabular}{|c|c|c|c|c|}
\hline Parameter & Value & $\begin{array}{c}\text { Reference } \\
\text { value }\end{array}$ & Parameter & Value \\
\hline $\begin{array}{l}\text { Haemoglobin } \\
(\mathrm{g} / \mathrm{dl})\end{array}$ & 14.2 & $11.8-15.8$ & Serum lgG (mg/dl) & Normal \\
\hline MCV (ff) & 89.1 & $80.4-96.4$ & Serum IgA (mg/dl) & Normal \\
\hline $\begin{array}{l}\text { Leucocytes } \\
\text { (/pl) }\end{array}$ & 10.04 & $4.0-10.0$ & Serum IgM (mg/dl) & Normal \\
\hline $\begin{array}{l}\text { Neutrophils } \\
(/ \mu l)\end{array}$ & 8,200 & $\begin{array}{l}1,800- \\
7,700\end{array}$ & Serum IgE (KU/I) & Normal \\
\hline $\begin{array}{l}\text { Lymphocytes } \\
(/ \mu l)\end{array}$ & 1,300 & $\begin{array}{l}800- \\
4,000\end{array}$ & ANAs & Negative \\
\hline $\begin{array}{l}\text { Platelets } \\
\left(\times 10^{9} / \mathrm{l}\right)\end{array}$ & 194 & $150-400$ & ANCAs & Negative \\
\hline $\begin{array}{l}\text { Creatinine } \\
(\mathrm{mg} / \mathrm{dl})\end{array}$ & 1.05 & $0.6-1.0$ & Gastrin (pg/ml) & Normal \\
\hline $\begin{array}{l}\text { Sodium } \\
(\mathrm{mmol} / \mathrm{l})\end{array}$ & 144 & $136-145$ & $\operatorname{VIP}(p m o l / l)$ & Normal \\
\hline $\begin{array}{l}\text { Potassium } \\
(\mathrm{mmol} / \mathrm{l})\end{array}$ & 2.7 & $3.5-5.1$ & Faeces calprotectin & Normal \\
\hline $\begin{array}{l}\text { Calcium } \\
(\mathrm{mg} / \mathrm{dl})\end{array}$ & 8.7 & $8.6-10.3$ & $\begin{array}{l}\text { Anti-transglutaminase } \\
\text { antibodies }\end{array}$ & Negative \\
\hline $\begin{array}{l}\text { Phosphorus } \\
(\mathrm{mg} / \mathrm{dl})\end{array}$ & 2.4 & $2.5-4.9$ & Antigliadin antibodies & Negative \\
\hline $\operatorname{CRP}(\mathrm{mg} / \mathrm{dl})$ & 0.16 & $0.01-0.82$ & HIV & Negative \\
\hline $\operatorname{ESR}(\mathrm{mm} / \mathrm{h})$ & 18 & $4-10$ & Toxocara canis serology & Negative \\
\hline $\begin{array}{l}\text { Albumin } \\
(\mathrm{g} / \mathrm{dl})\end{array}$ & 2.9 & $3.5-5.5$ & Fasciola serology & Negative \\
\hline TSH $(\mu / U / I)$ & 4.42 & $0.35-4.94$ & Histoplasma serology & Negative \\
\hline $\begin{array}{l}\text { Free T3 } \\
(\mathrm{pg} / \mathrm{ml})\end{array}$ & 2.86 & $1.71-3.71$ & Entamoeba serology & Negative \\
\hline
\end{tabular}

\begin{tabular}{|c|c|c|c|c|}
\hline Parameter & Value & $\begin{array}{c}\text { Reference } \\
\text { value }\end{array}$ & Parameter & Value \\
\hline $\begin{array}{l}\text { Free T4 } \\
\text { (ng/dl) }\end{array}$ & 0.91 & $0.70-1.48$ & Urine analysis & Normal \\
\hline AST (IU/I) & 46 & $8-35$ & & \\
\hline ALT (IU/I) & 57 & $7-45$ & & \\
\hline$A P(I U / I)$ & 44 & $30-120$ & & \\
\hline$y-G T(I U / I)$ & 27 & $<38$ & & \\
\hline $\begin{array}{l}\text { Total } \\
\text { bilirubin } \\
\text { (mg/dl) }\end{array}$ & 0.83 & $0.3-1.2$ & & \\
\hline LDH (IU/I) & 177 & $125-220$ & & \\
\hline PT (sec) & 10.9 & 11.4 & & \\
\hline aPTT (sec) & 22.1 & 28.0 & & \\
\hline $\begin{array}{l}\text { Folic acid (ng/ } \\
\text { ml) }\end{array}$ & 2.5 & $2.34-37.5$ & & \\
\hline $\begin{array}{l}\text { Vitamin B12 } \\
(\mathrm{pg} / \mathrm{ml})\end{array}$ & 384 & $187-883$ & & \\
\hline $\begin{array}{l}\text { Serum iron } \\
(\mu g / d l)\end{array}$ & 139 & $70-180$ & & \\
\hline $\begin{array}{l}\text { Ferritin } \\
(\mathrm{ng} / \mathrm{ml})\end{array}$ & 612 & $21-274$ & & \\
\hline $\operatorname{TIBC}(\mu g / d l)$ & 249 & $250-425$ & & \\
\hline $\begin{array}{l}\text { Fasting } \\
\text { cortisol } \\
(\mu \mathrm{g} / \mathrm{dl})\end{array}$ & 16.6 & $3.7-19.4$ & & \\
\hline
\end{tabular}

Table 1. Investigation findings

ALT: alanine transaminase; ANAs: antinuclear antibodies; ANCAs: anti-neutrophil cytoplasmic antibodies; AP: alkaline phosphatase; aPTT: activated partial thromboplastin time; AST: aspartate aminotransferase; CRP: C-reactive protein; ESR: erythrocyte sedimentation rate; $\gamma$-GT: gamma glutamyl transferase; HIV: human immunodeficiency virus; Ig: immunoglobulin; LDH: lactate dehydrogenase; MCV: mean corpuscular volume; PT: prothrombin time; TIBC: total iron biding capacity; TSH: thyroid-stimulating hormone; VIP: vasoactive intestinal peptide. 


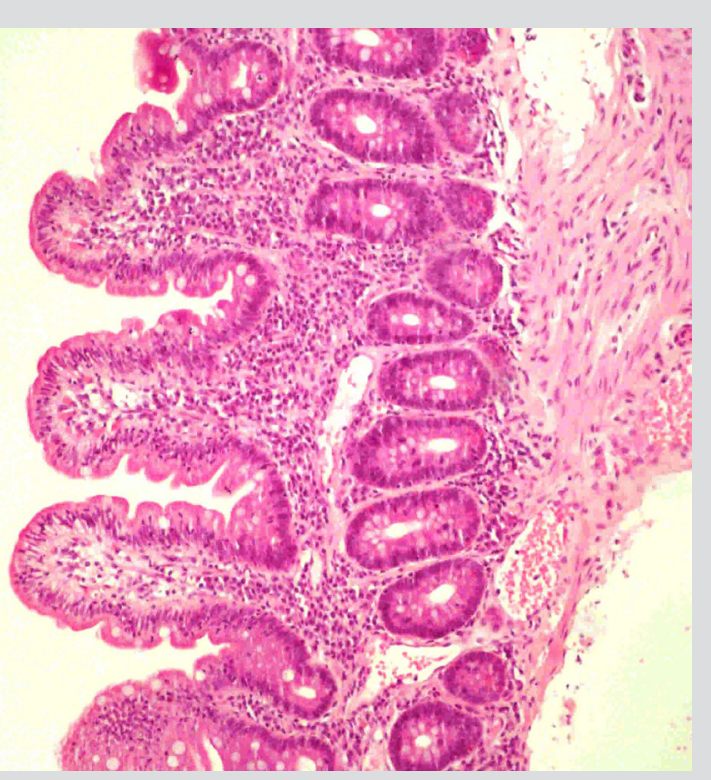

Figure 1. Duodenal mucosa with moderately villous atrophy

Upper gastrointestinal endoscopy was macroscopically normal with histology of duodenum (D3) biopsies showing moderate villous atrophy (Fig. 1). Lower gastrointestinal endoscopy including biopsies was normal. Thoracic, abdominal and pelvic CT scans were normal.

At this point the patient had lost a total of $20 \mathrm{~kg}$ and his blood pressure had dropped, so atenolol and clonidine were suspended. Simvastatin was also suspended. A gluten-free diet was initiated with no improvement, and fasting and a cholestyramine trial were attempted, also without improvement.

Following a literature review, olmesartan-induced enteropathy was suspected and the drug was halted. Two days later the diarrhoea stopped, the patient gradually gained weight, and the hypoalbuminaemia and hypokalaemia resolved. After 2 months, the patient had regained his normal weight. Interestingly, the patient restarted olmesartan autonomously due to his disbelief in the presumed aetiology, only for the symptoms to recur with diarrhoea restarting after 2 days of therapy and ceasing again 1 day after its discontinuation.

\section{DISCUSSION}

Olmesartan-induced enteropathy is an uncommon condition but should be considered in patients with chronic diarrhoea and evidence of villous atrophy. Since coeliac disease is the most common cause of villous atrophy ${ }^{[2]}$, it should be excluded through demonstration of negative coeliac serology or non-response to a gluten-free diet. Afterwards, a broad and challenging differential diagnosis should be pursued with exclusion of conditions such as Crohn's disease, enteric infections (e.g. Giardia lamblia), collagenous sprue, tropical sprue, common variable immunodeficiency, autoimmune enteropathy, haematological malignancies and medication-associated enteropathy ${ }^{[3]}$. An extensive and expensive medical evaluation is often pursued, as in our case, with inconclusive results.

After exclusion of the above conditions, olmesartan was considered a possible cause of the patient's symptoms, even though he had been taking the drug for about a decade. However, a latency time of 6-120 months has been described from first exposure to the onset of symptoms ${ }^{[4]}$. The exact mechanisms through which olmesartan induces malabsorptive enteropathy remains unknown, although the delay between onset of therapy and the development of symptoms suggests cell-mediated immunity damage rather than type I hypersensitivity ${ }^{[1]}$. Regarding treatment, previous reports have demonstrated clinical remission in all patients after the discontinuation of olmesartan ${ }^{[1,5]}$. In our patient we saw clinical improvement in 2 days and full clinical recovery after 2 months. Histological confirmation of improvement was not possible due to patient refusal of a repeat endoscopy.

Olmesartan-induced enteropathy is associated with quick mucosal recovery (a median of 8 months from its suspension to follow-up biopsies $^{[5]}$, in contrast to other enteropathies which take longer to histologically recover.

The authors report this clinical case to raise awareness of this recently described clinical entity, since olmesartan is a commonly prescribed anti-hypertensive drug. Negative serology for coeliac disease and the absence of a response to a gluten-free diet in patients taking this drug should suggest the possibility of this condition. If considered earlier in the work-up of chronic diarrhoea, olmesartan discontinuation could reduce the morbidity associated with the disease and avoid costly and unnecessary investigations. 


\section{REFERENCES}

1. Rubio-Tapia A, Herman ML, Ludvigsson JF, Kelly D, Mangan T, Wu T, et al. Spruelike enteropathy associated with olmesartan. Mayo Clin Proc 2012;87(8):732-738.

2. Jansson-Knodell CL, Hujoel IA, Rubio-Tapia A, Murray JA. Not all that flattens villi is celiac disease: a review of enteropathies. Mayo Clin Proc 2018;93(4):509-517.

3. DeGaetani M, Tennyson CA, Lebwohl B, Lewis SK, Abu Daya H, Arguelles-Grande C, et al. Villous atrophy and negative celiac serology: a diagnostic and therapeutic dilemma. Am J Gastroenterol 2013;108:647-653.

4. Adike A, Corral J, Rybnicek D, Sussman D, Shah S, Quigley E. Olmesartan-induced enteropathy. Methodist Debakey Cardiovasc J 2016;12(4):230-232.

5. Laniro G, Bibbò S, Montalto M, Ricci R, Gasbarrini A, Cammarota G. Systematic review: sprue-like enteropathy associated with olmesartan. Aliment Pharmacol Ther 2014;40:1623. 